FRANCIS OF ASSISI 


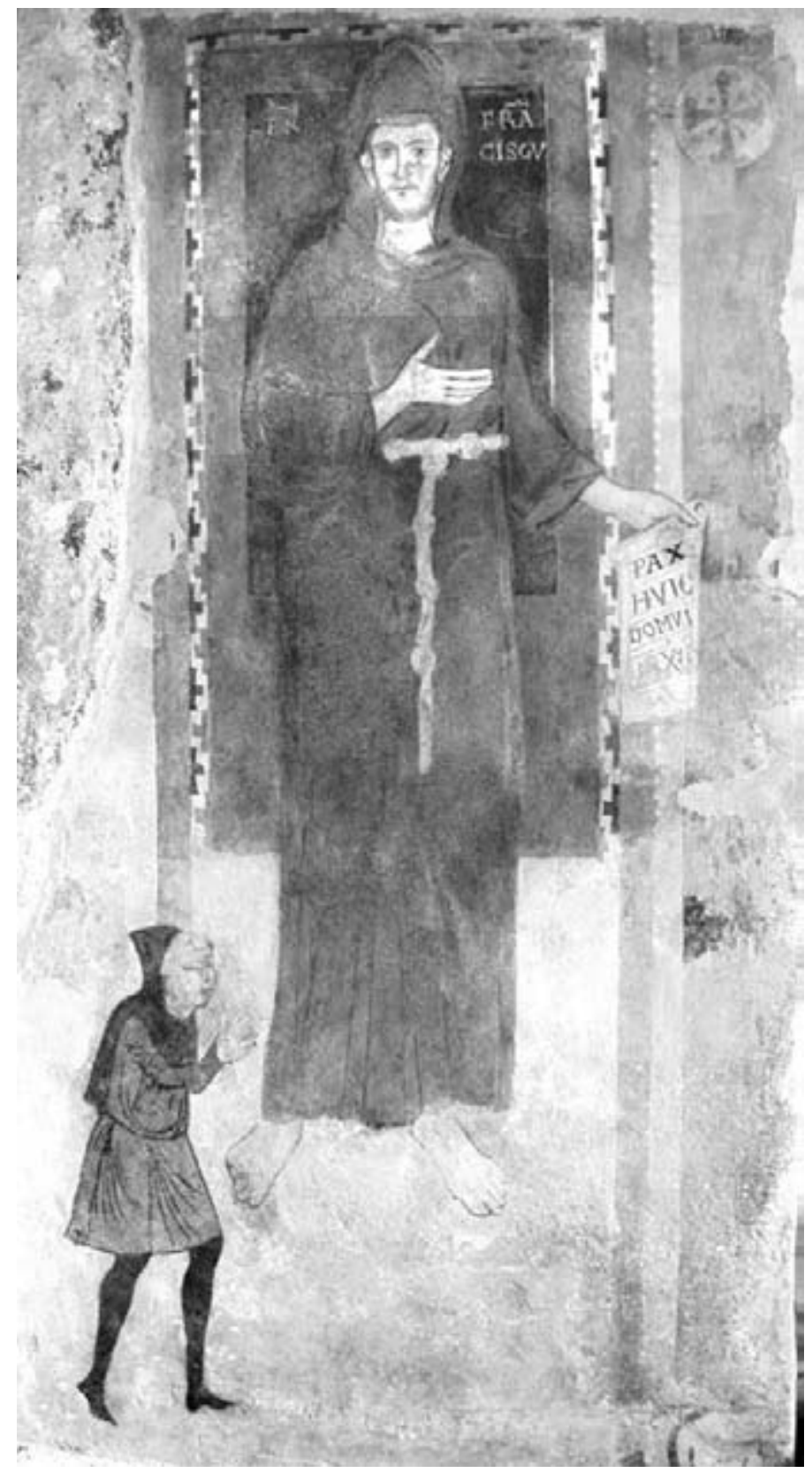




\section{FRANCIS OF ASSISI}

A New Biography

sero

[ Augustine Thompson, O.P. ]

Cornell University Press

ITHACA AND LONDON 


\section{FRONTISPIECE ILLUSTRATION}

Frater Franciscus, anonymous fresco, before 1228, Sacro Speco, Monastero di San Benedetto, Subiaco, Italy.

Used with permission.

\section{Copyright (C) 2012 by Cornell University}

All rights reserved. Except for brief quotations in a review, this book, or parts thereof, must not be reproduced in any form without permission in writing from the publisher. For information, address Cornell University Press, Sage House, 512 East State Street, Ithaca, New York 14850.

First published 2012 by Cornell University Press

Printed in the United States of America

\section{Library of Congress Cataloging-in-Publication Data}

Thompson, Augustine.

Francis of Assisi: a new biography / Augustine Thompson. p. cm.

Includes bibliographical references and index.

ISBN 978-0-8014-5070-9 (cloth: alk. paper)

1. Francis, of Assisi, Saint, 1182-1226. 2. Christian saintsItaly-Assisi-Biography. I. Title.

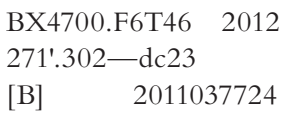

Cornell University Press strives to use environmentally responsible suppliers and materials to the fullest extent possible in the publishing of its books. Such materials include vegetable-based, low-VOC inks and acid-free papers that are recycled, totally chlorine-free, or partly composed of nonwood fibers. For further information, visit our website at www.cornellpress.cornell.edu. 